\title{
THE ROLE OF SOCIAL CAPITAL FOR SLOVENIAN HIGH-TECH COMPANIES' INTERNATIONALIZATION
}

\begin{tabular}{|c|c|}
\hline \multirow{3}{*}{ Abstract } & Alenka Pandiloska Jurak* \\
\hline & School of Advanced Social Studies, Slovenia \\
\hline & $\begin{array}{l}\text { The goal of the paper is to identify the importance and role of social capital accumulated in companies and state diplomacy } \\
\text { for companies' internationalization. The research aims to show the relations between the actors, to contribute to the discourse } \\
\text { between the actors, to suggest possible improvements, and thus to contribute to the success in the internationalization of com- } \\
\text { panies. The research approach is interdisciplinary. The paper offers not only a theoretical review and reflection but also new } \\
\text { findings resulting from the concretization of the topic based on an inductive approach-the case of the Republic of Slovenia. } \\
\text { The research has shown that the most important mechanisms for entering the market were product quality, brand, and personal } \\
\text { acquaintances. The results of the interviews showed the importance of personal acquaintances, combined with the implicit } \\
\text { knowledge, owned by the employees of the national institutions. }\end{array}$ \\
\hline Keywords & social capital $\bullet$ internationalization $\cdot$ high-tech companies $\cdot$ national institutions $\cdot$ state $\cdot$ diplomacy \\
\hline
\end{tabular}

\section{Internationalization Challenges}

For the successful international operations of companies in conditions of global competitiveness, it is necessary to identify key factors or mechanisms that enable the effective and successful expansion of the company to foreign markets, whether it is establishing a subsidiary, forming a multinational corporation, or solely establishing business relationships with foreign markets and suppliers. Many factors (Lamotte and Colovic 2015) are positively related to the likelihood that the company will internationalize from the beginning of its existence: access to Information and Communication Technology (ICT) infrastructures, European Union (EU) membership, competition, highly educated workers, home country networks and international networks developed because of foreign ownership. In contrast, early internationalization was negatively affected by uncertainty and, more surprisingly, knowledge intensity in the companies (Lamotte and Colovic 2015). The main positive effect of a business network for companies entering a foreign market is to provide support and information about the target market. Particularly important is the development of relationships with foreign business partners who play an important role in the capabilities and activities of the company (Seppo 2007). Boojihawon (2007) adds that internationalization decisions and growth patterns are largely shaped by their network of formal as well as informal relationships (Boojihawon 2007). Belso-Martinez (2006) notes that an active international profile and large-scale personal networks, largely contribute to access to markets and resources in a faster and more efficient manner.

Freeman, Edwards, and Schroder (2006) identified seven key variables in the case of Australian-based Small and medium enterprises (SMEs), which are positively related to the rapid internationalization of SMEs, two of them being (i) personal networks that provide the basis for building partnerships and alliances; (ii) adapting relationships over time so that they are lasting and meet the changing needs of partners and the development of new relationships to enter new product markets (Freeman, Edwards, and Schroder (2006).

Derived from these findings, this paper addresses the following research question: What is the role of the social capital accumulated in companies and state diplomacy for companies' internationalization?

To be able to find the answer to a complex question, we will be searching through the prism of an interdisciplinary approach. The article is structured in the following way: First, we will be addressing the challenges of internationalization,

\footnotetext{
*Corresponding author e-mail: alenka.pandiloska@fuds.si

(C) 2021 Alenka Pandiloska Jurak. This is an open access article distributed under the Creative Commons Attribution-NonCommercial-NoDerivs license (cc)) BY 
lightening the view of companies and the latest relevant research on this field. Second, we introduce social capital as a sociological perspective of actor relations. Third, the research methodology is explained, followed by the crucial findings of qualitative and quantitative research. Lastly, we present final remarks.

2. The Role and Importance of the State Market Intervention

Finding opportunities in other markets is important not only for the companies themselves but also for states. Export or export demand (Lah and Ilič 2007, 200) can be an important generator of economic growth, especially for smaller economies. Free trade (Morrison 2002, 255) benefits all states. States intervene in international trade for several reasons: nurturing young industries and promoting industrialization; protecting domestic employment, especially low-skilled, low-income cities; protecting consumers from dangerous products; protecting the national interest through government purchases in strategic industries, strategic trade policies, and a globally competitive industry; pursuing international politics; and maintaining a national culture and identity (Morrison 2002, 254-57; Coughlin, Chrystal and Wood 2004, 310-313).

Export or export demand (Lah and llič 2007, 200) can be an important generator of economic growth, especially for smaller economies. Because of their interest and the needs and requirements of the economy, countries formulate economic policies and, within their boundaries, legal and other resources that set the framework for implementation. In this way, they set rules for, on one hand, the work of domestic producers and service providers and, on the other, restrictions for foreign ones, thereby seeking to protect their economy. Economic policy should also include instruments to help companies to internationalize, talking about selling products or items and setting up subsidiaries in another market. Countries offer (Lah and llič 2007, 200) financial resources, their know-how and acquaintances in foreign markets to help companies enter foreign markets.

Capitalism drives competition, and the cost of protecting the industry can be huge. On the other hand, protecting national industry promotes independence and security. The employment rate can only be maintained through safeguards. A nation-aided industry can compete globally and increase national wealth. Finally, other countries will also help their industry ( Lah and Ilič 2007, 200) (which can no longer be understood as 'free trade'). States intervene in international trade for several reasons: nurturing young industries and promoting industrialization; protecting domestic employment, especially in low-skilled, low-income cities; protecting consumers from dangerous products; protecting the national interest through government purchases in strategic industries, strategic trade policies, and a globally competitive industry; pursuing international politics; and maintaining a national culture and identity (Morrison 2002, 254-57 and Coughlin, Chrystal, and Wood 2004, 310-13). The use of national measures to steer international trade is often governed by specific international criteria and arrangements, and its implementation is monitored through joint institutions, i.e., international economic organizations and agreements (Kumar 2007, 179).

\subsection{Economic protection and role of economic diplomacy} Modern economies are (due to globalization) increasingly involved in international economic flows (Lah and Ilič 2007, 200). Countries offer financial resources, their knowledge, and acquaintances in foreign markets to help companies' internationalization (Lah and Ilič 2007, 200). Institutionally, the state uses diplomacy in regulating this area, with a special branch in mind, i.e., economic diplomacy (Jazbec 2009, 77-80). It works from the perspective of nation-states and their governments in at least four institutionalized ways: (i) It takes place through the work of foreign ministries, which coordinate these processes to a certain extent and have a significant influence on them in terms of content. (ii) This form of diplomacy is also carried out by the competent ministries of economy and trade, as these ministries are the basic creator and promoters of economic policy. Some countries have special economic missions abroad, which are set up by the ministries of the economy themselves and are not part of diplomatic missions. (iii) Chambers, interest groups, and promotional nongovernmental institutions play an increasingly important and prominent role in the implementation of economic diplomacy. (iv) Many companies also participate in the implementation of this diplomacy as economic operators (Jazbec 2009, 7780). As explained by Okano-Heijmans (2011), economic diplomacy is a foreign policy practice and strategy that is based on the premise that economic/commercial interests and political interests reinforce one another and should thus be seen in tandem.

Diplomacy opens the door to foreign markets for the economy and helps it to make strategic alliances in strong competition. During their visits abroad, the highest state representatives also include economic delegations in their team. Government coordination of economic performance abroad is also common to achieve greater impact and ensure financial success (Jazbec 2009, 77-80). The foreign policy of small countries, such as Slovenia, is characterized by several specific features that those who decide on and implement foreign policy are obliged to consider (Petrič 2010, 444-63). Particularities are evident in the selection of objectives and appropriate 
resources, in the selection of strategy, and the organization and operation of their external service. Small countries do not have much power to use as a foreign policy tool, so they need more effective diplomacy than other countries (Petrič 2010, 444-63).

\subsection{Past challenges of Slovenia's market internationalization} Despite discussions (Cuervo-Cazurra 2012), there is increasing awareness that the internationalization of companies from Eastern European and Central European countries is following a slightly different path from that in developed economies. Companies in transition and emerging economies often operate in a domestic environment characterized by an institutional void and high regulatory uncertainty, which is not generally the case for developed economies (Cuervo-Cazurra 2012).

The independence of Slovenia in 1991 not only signified the political independence of the new state, which previously represented (see Ferfila et al. 2004) the most developed, industrialized, and most prosperous state of the former Yugoslavia, but also a turning point for its economy. With independence, Slovenia lost $45,2 \%$ of its exports, which also included a $74,1 \%$ drop in exports to the former Yugoslavia (Ferfila et al. 2004, 48). Turning outwards to other markets was necessary, but after independence, it turned out that, compared to the Western European economy, the Slovenian economy was rigid and unprepared for finding new opportunities in other markets. The products were not competitive enough, and the experience and knowledge of rapid transformation were not adequate. The economy needed a rebirth, a systemic transformation, and most of all, a leap in mindset in terms of quality, business style, business mindset, perception of its products, and the fact that they needed to be sold. During the transition, there was a collapse of some of the larger companies that, for various reasons, simply did not manage this new situation. Many new, small, and microcompanies emerged as supporters and/or suppliers to large and new players in the internal market. Despite these new players and the low number of their products or services, the internal market has become too small to ensure their existence. A company set up in such a small market seems to be in a worse position than the one where the number of customers is higher. A larger market can mean more competition and not necessarily greater purchasing power. However, competition also contributes to the quality of products and services, while a large purchasing power in a smaller market does not contribute much if it is too small.

The latest data show that Slovenia's exports represent more than $75.3 \%$ of the value of Slovenia's gross domestic product (MGRT 2021). There are many reasons and mechanisms that influenced the level of success in internationalization. In this paper, we are focusing on the role of social capital, which is accumulated in companies and through state diplomacy.
3. Social Capital

Hardly measurable and verifiable, but often the key to successful internationalization of a company is the socalled human factor, which encompasses all the noninstitutionalized elements of strengths and weaknesses that individuals possess as their personality traits. On one hand, they are institutionalized actors who operate based on legal relationships and, at the same time, are victims of the human factor exposed in individual interests, which are reflected through negotiation processes. Individual interests, which should not play any role in the context of institutionalized relations, are the real driver of any economic change and are mirrored through accelerations and inhibitions of the economic functioning of individual entities. In doing so, individual interests may use a variety of methods, from bribery and intimidation to obstruction of justice or their investment as an incentive to change the economic structure of an area.

Our research includes the study of the human factor through the prism of social capital. Social capital (see Bourdieu 2004, 317) is an aggregate of actual or potential assets. These are related to having a permanent network of institutionalized relationships of mutual acquaintance and group membership. It provides support to the joint ownership of each of its members. The amount of social capital that an actor possesses depends on the size of the network of connections that he or she can effectively mobilize, and on the amount of capital contributed by anyone to whom it is linked (Bourdieu 2004, 317). However, not all acquaintances serve this purpose. Only those who act as a bridge between network segments are important (Granovetter 1983). We are talking about networks called 'weak ties' or weak networks. Granovetter says (1983) that an individual with slightly weak ties is deprived of information from other parts of the social system and limited by his or her immediate environment. That is, those with weaker ties have more options in obtaining information. A social system (Granovetter 1983) where there is a lack of weak ties will be fragmented and unconnected.

Social capital is also defined by its function. It is not a unified entity, but a diversity of different entities that share two characteristics: they are all composed of some aspect of social structure and promote the specific actions of individuals within the structure (Coleman 1990, 383-401). Historically, a heavily bureaucratized and regulated socialist system forced it to function within informal mechanisms (Lomnitz 1988). Relying on personal networks and political commitments was probably a better economic strategy than following formal institutional arrangements. Given that the social organization of the economy is deeply rooted in 
collective consciousness and practice, it is also resistant to changing cultural circumstances (Biggart and Guillen 1999). This explains why the economic practices that developed during state socialism are still present, even though the regime as such has already collapsed (Bandelj 2002, 434). There are three groups of social capital in sociological theory: (i) bonding, which refers to closed networks, such as family and class; (ii) bridging, which relates to connecting individuals from different networks; and (iii) synergy between the two groups. We are interested in the definition of bridging social capital, whose main theorist is Bourdieu (1985).

As in economic relations, trust is an important element. Trust can be seen as part of a more complex image of social capital within societies (see Cepoi 2013; Cepo 2016; and Cepoi 2017). Consequently, we can understand why social capital and internationalization are key elements to increase the absorptive capacity of a cluster and its growth (Valdaliso et al. 2011). All dimensions (structural, relational, and cognitive) of social capital affect the acquisition of foreign market knowledge and financial resources. Further on, also that the use of individuals' social capital often changes during SMEs' internationalization (Lindstrand, Melén, and Nordman, 2011). Lindstrand and Hanell (2017) researched two forms of firmlevel social capital: inter-national social capital and marketspecific social capital and examine their effect on SMEs' exploitation of international business opportunities. They have concluded, that although international social capital is not a prerequisite for exploiting new business opportunities, this social capital can boost the effect of a market-specific social capital on firms' opportunity exploitation. Firms with both forms of social capital will therefore be able to exploit more business opportunities. Firms without a market-specific social capital will experience difficulties in the exploitation of new opportunities in international markets. These firms will not have the precise and accurate knowledge needed for exploiting new opportunities. Hence, without a marketspecific social capital, firms will face the 'liability of outsiders' and will encounter fewer opportunities for their international expansion (Lindstrand and Hanell 2017).

Our research derives from the above findings. It aims to show the role of social capital of different actors and how it can affect internationalization success. We will link the notion of personal acquaintance with the sociological notion of social capital. The study will determine whether companies perceive personal networks of individuals and identify them as relevant to the extent that an individual with a certain social capital has the advantage of employment. We will add the importance of the state as a network and an actor in the research. The internationalization of companies (see Musteen, Datta, and Francis 2014) from Central European countries is different from the path of internationalization of companies in developed economies. It is characterized by institutional void, regulatory uncertainty, and lack of formal institutions. Following these findings, we will provide a more detailed insight into this issue, both from the perspective of the real situation by companies and institutions, and the state. The insight into the importance of the state also follows the findings of Pustovrh and Rašković (2010)), who, in a sample of 177 high-tech companies (henceforth HTCs) in Slovenia (manufacturing and service companies included), researched innovative and technological breakthroughs. Among other things, they found that state support institutions are rated 3 out of 7 . Most companies believe that these institutions are uncoordinated (Rašković and Pustovrh 2010).

\section{Research Methodology ${ }^{1}$}

Several scientific research methods and techniques were used to address the research question. Based on the above rough outline of the general framework, the research work focused on the importance of social networks in the process of internationalization of a business. The first part of the research was carried out using a quantitative research methodology. The main reason for the selection is the possibility of generalizing the results to the population and the choice of objective measurement instruments. A survey was used to obtain key information. It allowed us to collect data across the entire population, in addition to ensuring anonymity and thus obtaining data that we would not otherwise have access to. In the first phase, a survey questionnaire was developed. In the second phase, a pilot survey was conducted on a sample of companies, which pointed out the possible shortcomings of the question posed. The entire population was surveyed. Data were processed by statistical analysis and interpreted in terms of content.

In our research, we limited ourselves to researching Slovenian HTCs as actors entering the markets of other countries. There are two reasons for this: First, technology is a key driver in the global economy (Morrison 2002, 279; also for more on innovation and digitalization see Besednjak Valič, 2019; Besednjak Valič et al. 2020; Besednjak Valič et al. 2021; Pandiloska Jurak 2020). In the context of economic globalization, technology is a key factor in enhancing growth and competitiveness in the business world. Technologyintensive companies have more innovation, are gaining new markets, are more productive in using the resources available, and generally provide more to the people they employ.

1 »Operation part-financed by the European Union, European Social Fund. Operation implemented in the framework of the Operational Programme for Human Resources Development for the Period 2007-2013, Priority axis 1: Promoting entrepreneurship and adaptability, Main type of activity 1.1.: Experts and researchers for competitive enterprises." 
HTCs are those whose products are the fastest-growing in international trade, and their dynamics help to improve efficiency in other sectors (Hatzichronoglou 1997, 4). Second, given the facts referred to in point one, it is appropriate to determine, from the perspective of the HTCs and the state what difficulties these companies face in internationalization and what the possibilities are for improving the situation.

A dedicated sampling method was used. The population is represented by HTCs in Slovenia. The designation of units in a population is based on the classification established by the Organisation for Economic Co-operation and Development (henceforth OECD). The OECD Secretariat identified the methods used to classify sectors and products by technology level and introduced two lists: one for activities (sector approach) and the other for products (product approach). The data used to compile the activity list are based on the International Standard Classification of Industrial Activities, ISIC Rev 2. The new classification covers only the manufacturing industry. R\&D intensity was identified as the only criterion, identifying four groups: high, medium-high, mediumlow, and low-tech (Hatzichronoglou 1997, 4-5). The productby-product approach was developed to supplement the list by activity and provides a more appropriate tool for analysing international trade. It is based on the Standard International Trade Classification, SITC Rev 3 (Hatzichronoglou 1997, 4).

Based on OECD classification, conversion to Slovenian Standard classification of activities (Standarsna klasifikacija dejavnosti - SKD) and data capture in The Slovenian Business Register (Javna baza podatkov o vseh poslovnih subjektih s sedežem na območju Republike Slovenije AJPES), we determined population units covering 364 companies as of March 25, 2011. The pilot survey was conducted in May 2011 and continued in April 2013. The survey was conducted on the entire population of Slovenian HTCs. There were $12.1 \%$ of questionnaires returned. The obtained data were processed in the SPSS program. Due to the small sample and missing answers to some questions, it was not possible to perform some comparative and sample statistical calculations. For some questions, due to the small size of the sample, the answers were pooled. In this way, a better picture of the respondents' opinions was shown. Due to the questionability of the representativeness of the sample, the two-sample KolmogorovSmirnov test was calculated based on the distribution of returned business questionnaires and the distribution of the population by region. The results showed that we could not claim that there was a difference between the sample and the population.

Since the survey can have many disadvantages (see Kumar 2005, 130), such as low responsiveness, and a lack of additional explanation (Kumar 2005, 130), the survey was followed by individual, structured interviews. These provided a more in-depth and substantive look at the topic. The survey results raised some new questions that anonymous interviews would not answer. Through the interviews, we also verified the results of the survey.

In the second part of the research, we used a qualitative research methodology, as we wished to: (i) check the results of the survey, (ii) get an in-depth insight into the reasons for the survey results, (iii) get a personal interpretation of key stakeholders regarding survey results, (iv) check the matching or divergence in stakeholder views, not only from the sphere of companies, but also from the public sphere and the sphere of economic associations. An interview can be a very rich source of data and allow an in-depth study of the phenomenon (Tratnik 2002; Vogrinc 2008). Interviewing allows for greater flexibility and retrieval of different, sometimes unplanned information, from the survey (Lamut and Macur 2012, 143). The sample size and the identification of relevant interviewees were determined based on the results of the survey analysis. After the interviews, qualitative content analysis was made. A dedicated sampling method was used. The interviewees were divided into three relevant spheres: public institutions, economic associations, and businesses. We identified two institutions/companies in each sphere. Interviewees were selected based on their workplace and experience in the subject area covered. In total, six interviews were conducted in July 2015. The questionnaire consists of four thematic sections, namely, (i) institutional assistance, (ii) non-institutional assistance, (iii) involvement in public policy networks and planning of strategic documents, and (iv) networking. It consists of eight questions. The qualitative content analysis of the interviews conducted in the research can be roughly divided into six steps (see Mesec 1997, 75): (1) editing material, (2) identifying coding units, (3) open coding, (4) selecting and defining relevant concepts and categories, (5) respectively, coding and (6) designing the final theoretical formulation (Mesec 1997, 75).

\section{Findings}

Based on the theoretical background and the conducted research, we herein present the most relevant findings, starting with one of the most important results of the survey: the conclusion that the most important mechanisms for entering the market were product quality (95\% for EU and European Free Trade Association (EFTA) markets, $70.6 \%$ for other markets), brand (67.5\% EU and EFTA markets, 51.5\% for other markets $\left.{ }^{2}\right)$ and personal acquaintances $(66,7 \% \mathrm{EU}$ and EFTA markets, $70.6 \%$ for other markets).

Social capital (as a network of personal acquaintances) about

2 All data refer to the answers, marked with 4 (very important) and 5 (crucial), chosen from a Likert scale 1 (not important) -5 (crucial). 
the company's own cultural and economic capital has proved to be of great importance for assisting in internationalization and as an opportunity to compete with other, more recognizable companies. We have found that personal acquaintances are one of the key mechanisms in entering the EU, EFTA (66.7\%), and other countries' markets $(70.6 \%)$. The basic condition for a successful business is the quality of the product so that the business can offer it to the potential client/partner, but the skills of grooming and maintaining personal acquaintances are crucial. According to the interviewees, foreign language skills, knowledge of foreign business culture rules, mastery of business etiquette, communication skills, and the ability to empathize with the needs/expectations of a potential partner are also important in this context.

We address social capital from two different standpoints. The first was evident in the results of the survey and was further confirmed by the results of the interviews. These are personal contacts and acquaintances of company employees. In the case of the EU and EFTA, companies consider them to be just as important as brand strength (66.7\%). The only important mechanism is the quality of the product $(95.3 \%)$. In the case of entering other countries' markets, they even go beyond the importance of the brand $(51.5 \%)$ and are equated with the quality of the products $(70.6 \%)$. Most companies agree that employees have made relevant acquaintances during their employment at their company (43.2\%), and even more have had them when they became their employees (66.75). Half of the respondents agree that a person with relevant contacts has a job priority. Personal acquaintances are more important to companies than presentations and visits to fairs (46.3\%), although they also attend and use these to make new contacts. If we consider Granovetter's theory on the importance of weak ties (see Granovetter 1983), it would be interesting to conduct further research on what the meaning of the presentations and visits to international fairs is. Besides direct sale, one would assume that networking and assuring 'weak ties' would be one of the most important aspects of such presentations and fairs. The second source of personal acquaintances comes from the acquaintances of employees in the institutions of the Republic of Slovenia. The results of the interviews showed the importance of these acquaintances and the lack of these. It was pointed out that diplomacy tends to be inefficient. A major drawback or reason for the inefficient functioning of the institutional mechanisms has also been the high staff turnover at embassies and in economic diplomacy. A direct consequence of the (too) frequent staffing at the national level in the (most common) periods of four years (e.g., the duration of the ambassadors' term of office) is the loss of networks and the intensities of connections that a national authority representative establishes during his/her business in a foreign market which the company wishes to enter. Interviewees have repeatedly pointed out that building a quality network of connections with relevant actors is a lengthy or multiyear process, but crucial for the internationalization of the company. The relevance of the existence of networks in the process of internationalization of a company relates primarily to the possibility of obtaining direct information on the characteristics of a foreign market or references of a potential business partner operating in the market which the company wishes to enter. It is about acquiring implicit knowledge from different actors in the internationalization process.

The data also show that, although the constraints that businesses often encounter are administrative and need to be addressed at the state-by-state level, companies are looking for other possible solutions because of distrust of their own country's institutions. Institutional mechanisms are generally less important for helping breakthroughs than non-institutional ones. According to the interviewees, such impulses are wrong and are the result of (1) poor self-knowledge of the company, (2) past negative experience of companies with national institutions, and (3) distrust of effective, proactive action in entering foreign markets. Negative experiences are the result of poor responsiveness of national actors in providing support or solving (usually very complex and difficult to solve) problems that affect and diminish the confidence of companies in national mechanisms of internationalization assistance.

The issue of professional competence of employees in national institutions or embassies and economic diplomacy has arisen because of the non-engagement of the state for better professional qualification of national representatives abroad. According to the interviewees, the problem is a mismatch between the supply of companies and the needs of (foreign) markets and the presence of Slovenian diplomatic missions/embassies in these markets. Activities carried out by national actors are often 'one-off episodes'. National actors do not collect feedback or conduct a continuous evaluation of the effectiveness of the event by participants.

In this regard, Slovenia's joining the EU membership has proved to be an important step. With Slovenia's EU membership, Slovenia has become an actor in the EU network, which (as a rule) is not aware of administrative and customs barriers ('gatekeeper' does not exist), which makes it much easier for companies to work. EU membership is one of the important mechanisms in entering the EU and EFTA markets $(61 \%)$ as well as the markets of other countries $(41.2 \%)$.

\section{Conclusion}

It was pointed out in the interviews that in the Slovenian space between national actors and economic entities, the understanding and awareness of the importance of interpersonal connections are lacking or are (even) presented 
with a negative connotation. The negative connotation with personal acquaintances was attributed to the Slovenian media by reporting on the (personal) use of political acquaintances. Nevertheless, personal acquaintances contribute to successful internationalization. Building a quality network of connections with relevant actors is a long-standing, but crucial process. Furthermore, establishing a relationship is a prerequisite that must be followed by the process of 'nurturing relationships'.

As Adam and Rončević (2002, 207-27 and 2003, 5-32) consider, social capital is a conceptual innovation in contemporary sociology and other social sciences, but it cannot be the only variable that can explain micro- and macrophenomena. Social capital must be used as part of a broader model that incorporates many sociocultural variables or factors (Adam and Rončević (2002, 207-27 and 2003, 5-32). Having that in mind, our additional findings give us needed ground for a better understanding of the phenomena. The relevance of the existence of networks in the process of internationalization of companies relates primarily to the possibility of obtaining direct information on the characteristics of a foreign market or the references of a potential business partner operating in the market which the company wishes to enter. As seen from the research results, acquiring implicit knowledge from different actors in the internationalization process is highly important. Social networks are important for businesses in terms of transferring the exchange of implicit knowledge. The transfer of implicit knowledge refers to the exchange of personal experience and knowledge, both in terms of the advantages and (potential) problems that companies are facing in internationalization.

It is interesting that companies seek knowledge, information, and social capital in the institutional framework of the state by trying to capitalize on the diplomatic network. It seems they expect this diplomatic network to accumulate that knowledge and social capital and to work in their favour, which shows the importance of the national institutions. Institutions are therefore not only important for regulation of matters through official channels, but also by owning the personal relations of employees. Given the demonstrated importance of this form of networking and concerning lack of knowledge, further actions in this regard should be carried out.

The research we conducted has some limitations. The first thing to note is the difficulty in defining the term 'high-tech enterprise'. Already in the introductory chapter, we have stated that we decided on a certain form of the term HTC. There are several definitions as we look for different types of HTC data capture during research. As a result, some findings are difficult to interpret; simply because of differences in statistics, the results are not comparable. A low number of HTCs in Slovenia also proved to be a limitation in the research. Despite sending the survey questionnaire to the entire population, we received a low number of responses. To tackle that issue, based on statistical verification, the doubt about the sufficient sample size was overridden. Additionally, the results of the surveys were also verified through interviews.

\section{References}

Adam, Frane. 2004. Kompendij socioloških teorij. 2. dopolnjena in popravljena izdaja. Ljubljana: Študentska založba."

Adam, Frane, Matej Makarovič, Borut Rončević, and Matevž Tomšič. 2005. The Challenges of Sustained Development. Budapest: Central European University Press.

Adam, Frane, and Borut Rončević. 2002. "Social Capital As Useful Scientific Metaphor". In Advances in Social Knowledge over Half a Century. Edited by Nikolai Genov. Paris: International Social Science Council. 207-234.

Adam, Frane, and Borut Rončević. 2003. "Social Capital: Recent Debates and Research Trends." Social Science Information. 42(2):155-183. doi:10.1177/0539018403042002001.

Bandelj, Nina. 2008. From Communists to Foreign Capitalists: The Social Foundations of Foreign Direct Investment in Postsocialist Europe Princeton, NJ: Princeton University Press.

Belso-Martinez, Jose A. 2006. "Why Are Some Spanish Manufacturing Firms Internationalizing Rapidly? The Role of Business and Institutional International Networks." Entrepreneurship \& Regional Development. 18 (3): 207-26. http://web.b.ebscohost.com/ehost/ detail/detail?sid=d1752b0f-ee5e-4151-a78b-68aaba2b30db\%40s essionmgr $120 \&$ vid $=0 \&$ hid $=106 \&$ bdata $=J \mathrm{mxhbmc} 9 \mathrm{c} 2 \mathrm{wmc} 2 \mathrm{I0ZT} 1 \mathrm{I}$ aG9zdC1saXZI\#AN=20917441\&db=buh

Besednjak Valič, Tamara. 2019. "Innovation, Digitalisation, and the HPC in the Danube Region." In Go with the Flow: High-Performance Computing and ilnovations in the Danube Region. Edited by Borut Rončević, Raluca Coscodaru, and Urška Fric. London; Budapest; Ljubljana: Vega Press. 22-46.

Besednjak Valič, Tamara, Janez Kolar, and Urša.Lamut, 2021. »Fighting the Big Bad Wolf of Global Trends: Technology Transfer between HPC Centres and SMEs. Digital Policy, Regulation and Governance (forthcoming). https://doi.org/10.1108/DPRG-112020-0162.

Besednjak Valič, Tamara, Janez Kolar, and Urša Lamut. 2020. „Three Scenarios of Innovation and Technology Transfer: The Case of Key Enabling Technologies in the Danube Region. « Journal of Engineering and Applied Sciences 15: 3619-23.

Biggart, Nicole Woolsey, and Mauro F. Guillén. 1999. "Developing Difference: Social Organization and the Rise of the Auto Industries of South Korea, Taiwan, Spain, and Argentina." American Sociological Review 64 (5): 722-47.http://www.jstor.org/ stable/2657373?seq=1\#page_scan_tab_contents.

Boojihawon, Dev K. 2007. "Network Dynamics and the Internationalisation Process of Small Advertising Agencies." Service Industries Journal. 27 (6): 809-29: http://web.b.ebscohost.com/ehost/detail/ 
detail?sid=d372f354-5d53-489f-88f5-363f2f8b0279\%40sessionm gr111\&vid=0\&hid=106\&bdata $=\mathrm{Jmxhbmc} 9 \mathrm{c} 2 \mathrm{wmc} 210 \mathrm{ZT} 1 \mathrm{laG} 9 \mathrm{zdC}$ 1saXZI\#AN=26447757\&db=buh.

Bourdieu, Pierre. 1985. "The Forms of Capital." In Handbook of Theory and Research for the Sociology of Education. Edited by J. H. Richardson. New York: Greenwood.. 241-58.

Bourdieu, Pierre. 2004. In. Kompendij socioloških teorij. Edited by Frane Adam. 2. dopolnjena in popravljena izdaja. Ljubljana: Študentska založba, 311-22.

Carlsson, Lars. 2000. "Policy Networks As Collective Action." Policy Studies Journal, 28(3): 502-20. http://splet03.izum.si:2054/pqdw eb? index $=0 \&$ did $=66273801 \&$ SrchMode $=1 \&$ sid $=15 \& \mathrm{Fmt}=4 \& \mathrm{VInst}$ $=P R O D \& V T y p e=P Q D \& R Q T=309 \& V$ Name $=P Q D \& T S=12767534$ $51 \&$ clientld $=72300$.

Cepoi, Victor. 2013. "Trust: A Diversity Approach." In Trust, Social cCpital and Democratic Participation. A ILterature rRview. Edited by Angi Daniela. Cluj-Napoca: Accent. 159-179

Cepoi, Victor. 2016. "Does Trust Make People More Civically Moral? An Empirical Study for the Romanian and Moldovan Societies." Raziskave in Razprave 9 (1-3): 264.

Cepoi, Victor. 2017. "Trust and Participation in the Information Society: New and Traditional Information Sources." In Information Society and Its Manifestations: Economy, Politics, Culture. Edited by Borut Rončević and Matevž Tomšič. Frankfurt am Main: PL Academic Research. doi: 10.3726/b10694.

Coleman, James S. 1990. "Socialni Kapital." In Kompendij socioloških teorij. Edited by Frane Adam. 2. dopolnjena in popravljena izdaja. Ljubljana: Študentska založba. 383-401.

Coughlin, Cletus C., Alec K. Chrystal, and Geoffrey E. Wood. 2004. "Protectionist Trade Policies: A Survey of Theory, Evidence and Rationale." In International Political Economy: Perspectives on Global Power and Wealth. Edited by Jeffry A. Frieden and David A. Lake. 4th ed. London: Routledge. 303-17.

Ferfila, Bogomil, Anton Grizold, John Loxley, and Paul Phillips. 2004. On the Sunny Side of the Alps: Historical, Political, Economic and Strategic Factors in Independent Slovenia Ljubljana: Fakulteta za družbene vede.

Freeman, Susan, Ron Edwards, and Bill Schroder. 2006. "How Smaller Born-Global Firms Use Networks and Alliances to Overcome Constraints to Rapid Internationalization". Journal of International Marketing. 14(3): 33-63. http://web.b.ebscohost.com/ehost/detail/ detail?sid=32329969-e56c-479d-8069-9ec62b2d5328\%40sessio nmgr110\&vid=0\&hid=106\&bdata $=J \mathrm{mxhbmc} 9 \mathrm{c} 2 \mathrm{wmc} 210 Z \mathrm{TT} 1 \mathrm{laG} 9 \mathrm{z}$ $\mathrm{dC1}$ saXZI\#AN=22383209\&db=buh.

Granovetter, Mark. 1983. "The Strength of Weak Ties: A Network Theory Revisited." Sociological Theory 1: 201-33. http://www.soc. ucsb.edu/faculty/friedkin/Syllabi/Soc148/Granovetter\%201983.pdf.

Hatzichronoglou, Thomas. 1997. Revision of the High-Technology Sector and Product Classification OECD Science, Technology and Industry Working Papers, 1997/02. Paris: OECD.http://search.
oecd.org/officialdocuments/displaydocumentpdf/?cote=OCDE/ GD\%2897\%29216\&docLanguage=En .

Jazbec, Milan. 2009. Osnove diplomacije.. Ljubljana: Fakulteta za družbene vede.

Kumar, Ranjit. 2005. Research Methodology: A Step-by-Step Guide for Beginners 2nd ed. London: Sage Publications.

Lah, Marko, and Branko llič. 2007. Temelji ekonomije. 2. dopolnjena izdaja. Ljubljana: Fakulteta za družbene vede.

Lamotte, Olivier, and Ana Colovic. 2015. "Early Internationalization of New Ventures from Emerging Countries: The Case of Transition Economies." M@n@gement. 18(1): 8-30. http://web.b.ebscohost. $\mathrm{com} /$ ehost/detail/detail?sid=acd43f71-5f01-4581-893f-b3cb8b792 a02\%40sessionmgr $111 \&$ vid $=0 \&$ hid $=106 \&$ bdata $=\mathrm{Jmxhbmc} 9 \mathrm{c} 2 \mathrm{wm}$ c2I0ZT1laG9zdC1saXZI\#AN=108638532\&db=buh.

Lamut, Urša, and Mirna Macur. 2012. Metodologija družboslovnega raziskovanja: Od zasnove do izvedbe. Ljubljana: Vega.

Lane, Jan-Erik, and Uwe Wagschal 2012. Culture and Politics. London: Routledge.

Lindstrand, Angelika, Sara Melén, and Emilia Rovira Nordman. 2011. "Turning Social Capital into Business: A Study of the Internationalization of Biotech SMEs." International Business Review 20(2): 194-212. https://doi.org/10.1016/j.ibusrev.2011.01.002.

Lindstrand Angelika, and Sara Melén Hanell. 2017. "International and Market-Specific Social Capital Effects on International Opportunity Exploitation in the Internationalization Process." Journal of World Business 52(5): 653-63. https://doi.org/10.1016/j.jwb.2017.05.002. Lomnitz, Larissa Adler. 1988. "Informal Exchange Networks in Formal Systems: A Theoretical Model." American Anthropological Association 90(1): 42-55. http://onlinelibrary.wiley.com/ doi/10.1525/aa.1988.90.1.02a00030/full.

Mesec, Blaž. 1998. Uvod v kvalitativno raziskovanje $v$ socialnem delu. Ljubljana: Visoka šola za socialno delo.

Ministrstvo za gospodarski razvoj in tehnologijo. 2021. Spodbujanje internacionalizacije. https://www.gov.si/teme/spodbujanje-internacionalizacije/.

Morrison, Janet. 2002. The International Business Environment: Diversity and Global Economy. New York: Palgrave.

Musteen, Martina, Deepak K. Datta, and John Francis. 2014. "Early Internationalization by Firms in Transition Economies into Developed Markets: The Role of International Networks." Global Strategy Journal 4(3): 221-37. http://web.b.ebscohost.com/ehost/detail/ detail?sid=49d55030-2fab-42ac-993b-b8ef46a2671d\%40session mgr $115 \&$ vid $=0 \&$ hid $=106 \&$ bdata $=J \mathrm{mxhbmc} 9 \mathrm{c} 2 \mathrm{wmc} 2 \mathrm{I0ZT} 1 \mathrm{laG} 9 \mathrm{zd}$ C1saXZI\#AN=97163052\&db=buh.

Okano-Heijmans, Maaike. 2011. "Conceptualizing Economic Diplomacy: The Crossroads of International Relations, Economics, IPE and Diplomatic Studies." The Hague Journal of Diplomacy 6(1-2), 7-36. doi: https://doi.org/10.1163/187119111X566742.

Pandiloska Jurak, A. 2020. »The Importance of High-Tech Companies for EU Economy: Overview and the EU Grand Strategies 
Perspective. « Research in Social Change 12(3): 32-52. doi:10.2478/ rsc-2020-0013.

Petrič, Ernest. 2010. Zunanja politika: osnove teorije in praksa. Ljubljana: Znanstvenoraziskovalni center Slovenske akademije znanosti in umetnosti.

Rašković, Matevž, and Aleš Pustovrh. 2010. Slovenska visokotehnološka podjetja na prepihu inovativne in razvojno tehnološke prebojnosti: Analiza stanja in potreb slovenskih visokotehnoloških podjetij. Ljubljana: Laboratorij za odprte inovacijske sisteme (LOIS), Center odličnosti za biosenzoriko, instrumentacijo in procesno kontrolo (CoBIK).

Seppo, Marge. 2007. "The Role of Business Networks in the Internationalization of Estonian Chemical Industry Enterprises." University of Tartu - Faculty of Economics \& Busi- ness Administration Working Paper Series. 50: 3-44. http://web.b.ebscohost.com/ehost/detail/detail?sid=169bb034d3b2-4745-bbb9-e034fa60e60b\%40sessionmgr120\&vid=0\&hid $=106 \&$ bdata $=J \mathrm{mxhbmc} 9 \mathrm{c} 2 \mathrm{wmc} 2 \mathrm{I0ZT} 1 \mathrm{laG9zdC} 1 \mathrm{saXZl \# db=bu}$ $h \& A N=24287396$.

Tratnik, Monika. 2002. Osnove raziskovanja v management. Univerza na Primorskem: Fakulteta za management.

Valdaliso Jesus, Aitziber Elola, Marijose Aranguren, and Santiago Lopez. 2011. "Social Capital, Internationalization and Absorptive Capacity: The Electronics and ICT Cluster of the Basque Country." Entrepreneurship \& Regional Development 23(9-10): 707-33. doi: 10.1080/08985626.2010.505268.

Vogrinc, Janez. 2008. Kvalitativno raziskovanje na pedagoškem področju. Ljubljana: Pedagoška fakulteta. 